\title{
Floristic Composition, Structure, Diversity and Conservation Strategies for Rehabilitation of Dry Tropical Forests in Buffer Zone of Achanakmaar Amarkantak Biosphere Reserve (AABR), India
}

\author{
Harischandra Darro ${ }^{1}$, S. L. Swamy*, Tarun Kumar Thakur ${ }^{2}$ and Alka Mishra ${ }^{3}$ \\ ${ }^{1}$ College of Agriculture, Katghora-Korba, \\ Indira Gandhi Agricultural University, Raipur, CG, India \\ ${ }^{2}$ Department of Environmental Science, \\ Indira Gandhi National Tribal University, Amarkantak, MP, India \\ ${ }^{3}$ Guru Ghasidas University, Bilaspur, CG, India \\ *Corresponding author
}

\section{A B S T R A C T}

K e y w o r d s
Biodiversity
conservation, Basal
area. Diversity
indices, Ecosystem
services

The present study was conducted to assess the floristics, structure and diversity of dry tropical forests in buffer zone of Achanakmaar-Amarkantak Biosphere Reserve. The biosphere is well recognized for its species richness and biological diversity. However, the increasing anthropogenic activities are causing rapid degradation of native ecosystem, especially the buffer and transition zones are severely affected and becoming ecologically fragile by disappearance of many valuable species. A line transect survey was conducted for inventorying floristic composition. The quadratic sampling approach was employed for determining the structure and diversity of forest types. Results on floristic composition shows that existence of forty three (43) species represented by 24 families, 13 species by 9 families and 16 species by 11 families in tree, shrub and herbaceous layers, respectively. The five vegetation types viz., Mixed Forest, Mixed Sal, Mixed Teak, Teak Mixed and Bamboo Brakes were identified. Density of trees ranged from 246 to 865 trees $^{-1}{ }^{-1}$. It was highest in Mixed Sal Forest and lowest in Bamboo Brakes. Average crop height and basal area of trees varied from 9.1 to $14.5 \mathrm{~m}$ and 12.1 to $29.9 \mathrm{~m}^{2} \mathrm{ha}^{-1}$. Shannon index values in tree layer ranged from 0.61 to 3.07 among different vegetation types in tree layer. It was highest in Mixed Forest and lowest in Teak Mixed Forest. Simpson index values ranged for 0.064 to 0.74 , which was found to be highest in Bamboo Brakes and lowest under Mixed Forest. The Evenness Index values ranged for 0.297 to 0.864, Margalef's Index from 5.30 to16.9. Beta Diversity across vegetation types ranged from 2.96 to 3.60. Mixed Forest showed highest beta diversity. The paper discusses implications of forest management for rehabilitation to conserve the fragile vegetation types of AABR.

\section{Introduction}

Climate change, global warming and biodiversity losses have emerged as serious environmental threats of 21 st century that impelled to increase the scientific efforts to bring resilience in native ecosystems for the sustainable supply of ecosystem services. Tropical forests are recognized as world's richest, complex, diverse and self-sustaining terrestrial ecosystems provides many products and services vital for sustenance of human 
societies. However, the treasure house of biological richness of tropical forests is depleting at alarming rates in last few decades due to overexploitation and adoption of unscientific management practices. The intrinsic ability of self-sustenance of tropical forests are losing gradually by the awful activities of over grazing, increased logging, encroachments, illegal mining, construction of dams, reservoirs etc. The structure and functioning of ecosystems are affected by rising anthropogenic activities. The dry tropical forests are covered in $38.2 \%$ of the total forest area of India (MoEF 1999), which is largely disturbed by lopping, burning, overgrazing and clearing for cultivation. Such disturbances lead to their conversion into species-poor forest ecosystems. Habitat destruction is main cause of species extinction and biodiversity losses in natural ecosystems (Koh et al., 2004; Pimm \& Raven 2000).

Tropical moist and dry deciduous forests in India are most exploited due to easy access as large number of population is living in vicinity of these forests. As consequence of burgeoning population and growing demands, the tropical forests of Central and Eastern India are rapidly deteriorating and gradually replaced by undesirable species. The livelihood and economy of many societies are depending up on well-being of these forests. Several initiatives were taken to protect the biodiversity of fragile tropical ecosystem. Under Man and Biosphere (MAB) programme of UNESCO, eighteen biosphere reserves were established across the country.

Achankmaar- Amarkantak Biosphere Reserve (AABR) is one among them declared as $14^{\text {th }}$ Biosphere Reserve on $30^{\text {th }}$ March 2005 by Ministry of Forests \& Environment, Govt. of India. AABR is one of the unique reserve represents tropical deciduous forest ecosystems, recognized as heritage site of UNESCO in Central India, which is severely affected by continuous biotic interferences due to increased demand for wood and nonwood forest products in the last few decades (Kittur et al., 2014). The buffer and transitions zones are highly fragmented and disturbed due to encroachments, construction of dams, roads, settlements, electrical transmission lines, excessive mining, unmanaged tourism, grazing etc. The conversion of dense forests into open forests, grasslands to agriculture systems might result in loss of biodiversity and also release large amount of $\mathrm{C}$ into the atmosphere. In this context, it becomes imperative to understand the changes in pattern of vegetation structure, composition and diversity in different vegetation types to bring resilience and arrest the process of degradation especially in buffer zone of biosphere reserve. Phyto-sociological analysis helps in understanding species assemblages and interactions.

The floristic composition, diversity and vegetation structure are key elements to characterize the anthropogenic activities as well as environmental factors affecting the vegetation and further understanding status of tree population, regeneration, and diversity for prioritizing measures of conservation. Species composition and dynamics provides the necessary context for management planning and development strategies for achieving sustainable management of forests and also for interpreting long term ecological research.

As the long term ecological studies are important to improve our understanding about the relationship between vegetation and environment and also for documenting the responses to climate change. Monitoring of ecological changes in forest structure and composition is also essential for successful implementation of REDD+ in this area. However, there is paucity of such valuable information since forest management needs 
accurate data on forest resources. Therefore, the present study is conducted to assess the floristic composition, structure and diversity of vegetation types of AABR and evolve suitable conservation strategies to counteract losses in biodiversity of fragile buffer zone.

\section{Materials and Methods}

\section{Study area}

The study was conducted in Khuriya Forest Range of Mungeli Forest Division, Chhattisgarh India situated between $21^{\circ}$ $48^{\prime} 35^{\prime \prime}$ to $22^{\circ} 40^{\prime} 30^{\prime \prime}$ North latitudes and $81^{\circ}$ $29^{\prime} 45^{\prime \prime}$ to $82^{\circ} 02^{\prime} 10^{\prime \prime}$ East longitudes. It forms the part of buffer zone of Achanakmaar Amarkantak Biosphere Reserve (AABR). The location of study area is depicted in Figure 1. The study area represents sub-humid climate with average annual rainfall ranging between $1200-1400 \mathrm{~mm}$, of which $90 \%$ is received from south west monsoon during JuneOctober (Kittur et al., 2014). The peak rainfall occurs in July-August months. Number of rainy days varies from 71-118 days. The altitude varies from 450 to 812.27 $\mathrm{m}$ above msl. The mean temperature in January is about $21^{\circ} \mathrm{C}$ and in May temperature rises between $31^{\circ} \mathrm{C}$ and $41^{\circ} \mathrm{C}$. The mean annual temperature ranges from $21^{\circ} \mathrm{C}$ to $31^{\circ} \mathrm{C}$ (Kittur et al., 2014). The topography is flat to undulating with depressions with small mountains, gorges scattered with trees and dense shrubs of natural vegetation. The soils of the area are generally lateritic, alluvial and black cotton types, derived from granite, gneisses and basalts. Soils were mainly grouped into three classes viz., Inceptisols, Alfisols and Vertisols.

\section{Materials}

Reconnaissance survey was conducted in Khuriya range, buffer zone of $A A B R$ to analyze floristic diversity and structure of vegetation. The forests represent Malayan realm covered with typical Tropical Dry and Moist Deciduous Forests with Sal and Mixed forests. The general floristic composition was recorded along $10 \mathrm{~km}$ line transect from centre in East-West and North South direction. At every $200 \mathrm{~m}$ intersection of transect, the details of composition in tree, shrub and herbaceous layers were recorded in $20 \times 20 \mathrm{~m}, 2 \times 2 \mathrm{~m}$ and $0.5 \times 0.5 \mathrm{~m}$ quadrates, respectively. Five (5) major types of forests viz., mixed forest, mixed sal forest, mixed teak forest, teak mixed forest and bamboo brakes were identified.

The structure and composition of vegetation were analyzed by following quadratic sampling approach. The community characterization of vegetation was done by randomly laying 10 quadrates in each forest type. Girth at breast height $(\mathrm{GBH})$ of trees was measured at $1.37 \mathrm{~m}$ on trunk of trees and collar diameter at $10 \mathrm{~cm}$ on the stem above the ground level for shrubs. Measuring tape was used for taking girth. Basal area of trees was calculated as cross sectional area of stem at breast height i.e. at $1.37 \mathrm{~m}$, while in shrubs it was calculated as cross sectional area of collar diameter. The vegetation data was quantitatively analyzed for frequency, density and abundance as per standard phytosociological methods (Curtis and McIntosh, 1950). Relative density, relative frequency, and relative basal area were computed following Phillips (1959).

The summation of relative frequency, relative density, and relative basal area values represented Importance Value Index (IVI) (Curtis and McIntosh, 1950). The basal area/basal cover values were used to calculate diversity parameters for tree, shrub and herbaceous layers. Diversity indices viz., Shannon-Wiener index (Shannon and Weiner, 1963), Concentration of DominanceSimpson's Index (Simpson, 1949), Species 
Richness (Margalaf, 1958), Equitability (Pielou, 1969), Beta diversity (Whittaker, 1975) were calculated as methods suggested by Thakur (2018).

\section{Results and Discussion}

\section{General floristic composition}

General composition of vegetation of Khuriya range of AABR reflects typical dry tropical forest ecosystem. A sum total of forty three (43) species represented by 24 families, 13 species by 9 families and 16 species by 11 families were found in tree, shrub and herbaceous layers, respectively (Table 1 and 2). Terminalia tomentosa, Shorea robusta, Syzygium cumini, Cleistanthus collinus, Tectona grandis, Diospyros ebenum, Couroupita guianensis, Lagerstroemia speciosa, Diospyros melanoxylon etc. were found to be dominant species in tree layer. On the other hand, Smilax macrophylla, Ventilago calyculata, Butea superba species in shrub layer, Convolvulus arvensis, Echinochloa colona, Curculingo orchioides, Senna tora, Ocimum tenuiflorum etc were found as dominant vegetation in herb layer.

The most abundant family was Fabaceae, which recorded highest number of individuals in both tree and shrub layers, respectively, while in herbaceous layer, both Poaceae and Asparagaceae families recorded maximum number (3) of individuals (Table 1 and 2). The spectrum of all species constituted a total 72 taxa represented by 36 families; the largest number (9) was represented by a single family Fabaceae. Four (4) species each was recorded by 3 families (Poaceae, Cesalpiniaceae and Anacardiaceae), while three (3) each by 5 families (Asparagaceae, Ebenaceae, Phyllanthaceae, Rubiaceae, Combretaceae), two (2) each by nine families and one (1) each species was represented by 18 families (Table 1 and 2).
The findings on vegetation composition of this study is comparable to those reported by Thakur et al., (2018), who found that 34 species represented by 13 families in overstorey and 16 species by 9 families in understorey vegetation in moist deciduous forests of AABR, Amarakantak, MP. Comparatively a higher number of species occurred in the present study might be ascribed to better microclimatic, edaphic and topographic conditions of site.

The present study site was in lower elevation range with dry conditions and alluvial compared to the study sites of Thakur et al., (2018), which was in higher elevations of AABR with sandy loam in nature. The past studies showed that nutrient-rich alluvial valleys supported the most diverse forests, moving uphill resulted in a steady decline in tree diversity (Aiba et al., 2005; Sullivan et al., 2017; Jucker et al., 2018) but still mechanism is not fully understood, how diversity gets regulated by dynamic edaphic and topographic gradients in tropical forests (Huston, 1980).

\section{Structure of various forests}

Structural variation in forests revealed that density of trees ranged from 246 to 865 trees ha $^{-1}$ (Fig. 2) It was highest in Mixed Sal forest and lowest in Bamboo brakes. Density of trees in different forest types was in the order: Mixed Sal Forest > Mixed Forest > Mixed Teak > Teak Mixed > Bamboo Brakes. Average crop height and basal area of trees varied from 9.1 to $14.5 \mathrm{~m}$ and 12.1 to $29.9 \mathrm{~m}^{2}$ $\mathrm{ha}^{-1}$, respectively (Fig. 3). Mean tree height as well as basal area values were found to be highest in Mixed Sal forest, while these were lowest in bamboo brake and teak mixed forests, respectively. Basal area in different forest types followed the order: Mixed Sal > Mixed Forest > Mixed Teak > Bamboo Brakes > Teak Mixed Forests. The patterns 
of structure, composition and diversity of vegetation recorded in the present study are closely resemble and comparable to other tropical forest ecosystems studied by earlier workers (Bijalwan et al., 2010; Naidu and Kumar, 2016; Thakur et al., 2019). Thakur et al., (2018) in a study on moist tropical ecosystem in Amarkantak MP reported density of over storey and under storey vegetation accounted for 553.68 trees ha (ranged from 424 to 752 trees $\mathrm{ha}^{-1}$ ) and 5870 shrubs ha- ${ }^{-1}$.

Slightly a higher density of trees in the present study is attributed to better site quality and microclimatic conditions. It has long been recognized that soil fertility and environmental conditions are the major drivers that influence the structure and diversity of tropical forests. Basal area of tree layer in the present study are well within the range and consistent with the findings of earlier workers (Krishnamurthy et al., 2010; Bijalwan et al., 2010; Bargali et al., 2014; Thakur et al., 2014, 2019 and Yadav et al., 2019). Thakur et al., (2014) reported that tree basal area ranged from 8.13 to $28.87 \mathrm{~m}^{2} \mathrm{ha}^{-1}$ in dry tropical forests of Barnowpara, Chhattisgarh. Jha and Singh (1990) also reported 6.58 and $23.21 \mathrm{~m}^{2} \mathrm{ha}^{-1}$ basal area in Vindhyan range of U.P. India. Thakur et al., (2018) in a recent study found that basal area of trees ranged from 8.33 to $29.93 \mathrm{~m}^{2} \mathrm{ha}^{-1}$ in moist deciduous forests of AABR, Madhya Pradesh.

Shorea robusta, Terminalia tomentosa and Syzygium cumini in Mixed forest, Shorea robusta, Terminalia tomentosa and Cleistanthus collinus in Mixed Sal Forest, Tectona grandis, Diospyros ebenum and Courouptia guianensis in Mixed Teak Forest, Tectona grandis, Lagerstroemia speciosa and Diospyros melanoxylon in Teak Mixed Forest, Dendrocalamus strictus, Bahunia racemosa and Terminalia tomentosa in
Bamboo brakes were identified as predominant plant communities in tree layer (Table 3). The results on structure of shrub and herbaceous vegetation are illustrated in Table 4. In shrub layer, Smilax macrophylla, Gymnema sylvestris, Agave americana, Jatropha curcas, Nyctanthes arbor-tristis, Discorea hispida etc associations were found as predominant plant communities in different vegetation types (Table 4).

\section{Diversity analysis of dry tropical forest}

Results on diversity analysis of vegetation are presented in Table 5. Shannon index values in tree layer ranged from 0.61 to 3.07 among different vegetation types. It was highest in Mixed Forest, and lowest in Teak Mixed Forest. Simpson Index values ranged for 0.064 to 0.74 , which was found to be highest in Bamboo Brake and lowest under Mixed Forest. The Evenness Index values ranged for 0.297 to 0.864 . It was highest in Mixed Forest and lowest in Teak Mixed Forest. The Margalef's Index values ranged from 5.30 to 16.9, which was highest in Mixed Forest and lowest in Teak Mixed Forest. Beta Diversity across vegetation types ranged from 2.96 to 3.60. Mixed Forest showed highest beta diversity (3.60) followed by Bamboo Brakes (3.33) and it was lowest in Mixed Sal Forest (2.96). In Shrub layer, Shannon Index values ranged from 0.54 to 1.54 across different vegetation types (Table 5).

Diversity Values were higher in Mixed Teak Forest followed by Mixed Sal Forest and Teak Mixed Forest and lowest values were observed in Bamboo Brakes. Simpson Index values ranged from 0.267 to 0.7 . The highest values recorded by Bamboo Brakes (0.7) and lowest values by Mixed Teak Forest (0.267). Evenness index values ranged from 0.49 to 0.861, the highest values was found in Mixed Teak Forest and lowest in Bamboo Brakes. The Margalef's Index values ranged from 0.60 
to 1.127. It was highest in Mixed Forest and lowest in Bamboo Brakes. Beta diversity values ranged from 2.14 to 3.75 among vegetation types. The diversity was highest in Mixed Forest and the lowest in Bamboo Brakes. In the herbaceous layer, Shannon Index values ranged from 0.624 to 2.01 (Table 5). It was higher in Teak Mixed Forest followed by Mixed Teak Forest and Mixed Sal Forest and lowest values were observed in Mixed Forest. Simpson index values ranged from 0.003 to 0.259 . The higher values were recorded in Mixed Sal Forest and lowest in Mixed Forest. Evenness Index values ranged from 0.271 to 0.89. Bamboo Brake recorded highest Evenness values, while it was lowest in Mixed Forest. The Margalef Index values in vegetation types ranged from 1.75 to 3.51 . The highest value was recorded by Teak Mixed Forest and lowest by Bamboo Brakes. The Beta diversity values ranged from 1.5 to 3.03 in the vegetation types. It was highest in Mixed Forest and lowest in Bamboo Brakes (Table 5).

Species diversity, the number of species in a community is ecologically important as it represents the spatial heterogeneity and niche differentiation for resource sharing among vegetation communities. The results revealed that species diversity varied across vegetation types of dry tropical ecosystem of Achanakmaar Amarkantak Biosphere Reserve (AABR). The diversity indices under this study are comparable to the indices reported in different tropical forests (Singh and Singh 1991; Thakur et al., 2014; Bijalwan et al., 2010; Bargali et al., 2014; Yadav et al., 2019). Singh and Singh (1991) recorded the Shannon-Wiener index values from 1.9 to 2.8 , concentration of dominance from 0.18 to 0.75 , species richness from 0.21 to 0.93 , and beta diversity of 3.1 in Dry deciduous forests of Vindhyan ranges of Uttar Pradesh, India. Similarly, Yadav et al., (2019) reported the Shannon Index values ranged from 2.39 to 3.62 , concentration of dominance from 0.12 to 1 in different tropical forest fragments of Barnowpara and Amarkantak. The present study also demonstrated inverse relationship between the diversity and dominance indices, which was corroborated by the several reports (Singh and Singh, 1991; Thakur et al., 2014; Yadav et al., 2019). The present study also showed highest (3.6) beta diversity in Mixed Forest and lowest (2.96) in Mixed Sal Forest clearly indicates the habitat heterogeneity level, as more number of species efficiently sharing resources and niche space in former compared to later forest type. The results are very well supported with findings of Yadav et al., (2019).

Biosphere reserves in India are declared under Man and Biosphere Reserve Programme of UNESCO to foster biodiversity conservation, maintain ecosystem structure and functioning to benefit local and global communities. Four kinds of ecosystem services viz., provisioning, regulatory, supporting and regulatory services are mainly recognized for exploiting dynamic interactions between ecosystem and societies for sustainable development (Kittur et al., 2014). The flow of ecosystems services to societies are modulated by species composition, structure, diversity, management regimes, land tenure, usufruct rights and forest policies.

$\mathrm{AABR}$ is one of the important biosphere reserves in Central India, which consists of moist Sal, dry Sal, dry Mixed deciduous forests and manmade plantations. Vegetation of moist and dry sal forests in core and buffer zones are very important for in-situ conservation, which are mainly affected by severe biotic pressures in Khuriya range. As the total area of biosphere is spread in 418 villages, of which 16 are situated in core zone, 99 in buffer and remaining 303 in transition zones (Thakur, 2018). 
Table.1 Floristic composition of tree layer of vegetation in Khuriya Forest Range of Mungeli Forest Division Chhattisgarh, India

\begin{tabular}{|c|c|c|c|}
\hline S. No. & Botanical Name & Common Name & Family \\
\hline 1 & Adina cordifolia (Roxb.) Hook.F & Haldu & Rubiaceae \\
\hline 2 & Anogeissus latifolia (Roxb. ex DC.) & Dhawra & Combretaceae \\
\hline 3 & Bauhinia malabarica (Roxb.) & Amti & Caesalpiniceae \\
\hline 4 & Bauhinia racemosa (Lam.) & Sampati & Caesalpiniceae \\
\hline 5 & Bombax ceiba $(\mathrm{L})$. & Semal & Bombacaceae \\
\hline 6 & Bridelia retusa (L.) A. Juss. & Redi & Phyllanthaceae \\
\hline 7 & Buchanania lanzan (Spreng.) & Char & Anacardiaceae \\
\hline 8 & Butea monosperma (Lam.) Taub. & Palas & Fabaceae \\
\hline 9 & Careya arborea (Roxb.) & Kumbhi & Lecythidaceae \\
\hline 10 & Cassia fistula (L.) & Amaltas & Caesalpiniaceae \\
\hline 11 & Chloroxylon swietenia (Roxb.) DC. & Bhirra & Rutaceae \\
\hline 12 & Cleistanthus collinus ( Roxb.) & Karra & Phyllanthaceae \\
\hline 13 & Cordia dichotoma ( G Forst) & Bohar & Boraginaceae \\
\hline 14 & Couroupita guianensis (Aubl.) & Nagalingam & Lecythidaceae \\
\hline 15 & Dalbergia paniculata ( Roxb.) & Dhobin & Fabaceae \\
\hline 16 & Dendrocalamus strictus ( Roxb.) & Bans & Poaceae \\
\hline 17 & Diospyros ebenum J. König & Ebony & Ebenaceae \\
\hline 18 & Dillenia pentagyna (Roxb.) & Karkota & Dilleniaceae \\
\hline 19 & Diospyros melanoxylon (Roxb.) & Tendu & Ebenaceae \\
\hline 20 & Diospyros montana (Roxb.) & Patwan & Ebenaceae \\
\hline 21 & Dolichandrone falcata (Seem.) & Pandri & Bignoniaceae \\
\hline 22 & Grewia tiliifolia (Vahl.) & Dhamin & Tiliaceae \\
\hline 23 & Lagerstroemia speciosa (L.) Pers. & Sena & Lythraceae \\
\hline 24 & Lannea coromandelica (Hout.) Merr. & Moyan & Anacardiaceae \\
\hline 25 & Madhuca longifolia (J. Konig) J.F.Macbr & Mahua & Sapotaceae \\
\hline 26 & Mallotus phillippensis (Lam.) Muell.Arg & Rohini & Euphorbiaceae \\
\hline 27 & Mitragyna parvifolia (Roxb.) Korth & Mundhi & Rubiaceae \\
\hline 28 & Morinda tinctoria (Roxb.) & Gunja & Rubiaceae \\
\hline 29 & Ougeinia oojeinensis (Roxb. ) & Tinsa & Fabaceae \\
\hline 30 & Phyllanthus emblica (L.) & Aonla & Phyllanthaceae \\
\hline 31 & Pterocarpus marsupium ( Roxb.) & Bija & Fabaceae \\
\hline 32 & Radermachera xylocarpa (Roxb.) & Garun & Bignoniaceae \\
\hline 33 & Schleichera oleosa (Lour.) Oken & Kusum & Sapindaceae \\
\hline 34 & Semecarpus anacardium (Linn.) & Belwa & Anacardiaceae \\
\hline 35 & Shorea robusta ( Roth). & Sal & Dipterocarpaceae \\
\hline 36 & Spondias mangifera (Willd.) & Amera & Anacardiaceae \\
\hline 37 & Sterculia urens (Roxb.) & Kullu & Sterculiaceae \\
\hline 38 & Syzygium cumini (L.) Skeels. & Jamun & Myrtaceae \\
\hline 39 & Tectona grandis (L.f.) & Teak & Lamiaceae \\
\hline 40 & Terminalia chebula (Retz.) & Harra & Combretaceae \\
\hline 41 & Terminalia tomentosa (Roxb.) & Saja & Combretaceae \\
\hline 42 & Vachellia nilotica (L.) & Babul & Fabaceae \\
\hline 43 & Ziziphus xylopyrus (Retz.) & Ghont & Rhamnaceae \\
\hline
\end{tabular}


Table.2 Composition of shrubs, climbers and herbs in Khuriya Forest Range of Mungeli Forest Division Chhattisgarh, India

\begin{tabular}{|c|c|c|c|}
\hline \multicolumn{4}{|c|}{ Shrub vegetation } \\
\hline S. No. & Botanical Name & Common Name & Family \\
\hline 1 & Agave americana (L.) & Sisal & Asparagaceae \\
\hline 2 & Bauhinia vahlii (Wight \& Arn.) & Mahul & Caesalpiniceae \\
\hline 3 & Butea superba (Roxb.) & Palas & Fabaceae \\
\hline 4 & Dioscorea daemona (Roxb.) & Bechandi & Dioscoreaceae \\
\hline 8 & Dioscorea hispida (Dennst.) & Doychi & Dioscoreaceae \\
\hline 6 & Gymnema sylvestre (Retz.) & Gudmar & Asclepiadaceae \\
\hline 7 & Ichnocarpus frutescens (Br.) & Dimerbel & Apocyanaceae \\
\hline 5 & Jatropha curcus (L.) & Ratanjyot & Euphorbiaceae \\
\hline 9 & Milletia extensa (Benth.) & Gouj & Fabaceae \\
\hline 10 & Nyctanthes arbor-tristis (L.) & Paarijat & Oleaceae \\
\hline 11 & Smilax ovalifolia (Roxb.) & Karua & Liliaceae \\
\hline 12 & Spatholobus roxburghii & Nasbel & Fabaceae \\
\hline 13 & Ventilago denticulata (Willd) & Kewtin & Rhamnaceae \\
\hline \multicolumn{4}{|c|}{ Herbaceous vegetation } \\
\hline S. No. & Botanical name & Common Name & Family \\
\hline 1 & Achyranthes aspera (Linn.) & Chirchita & Amaranthaceae \\
\hline 2 & Asparagus racemosus ( Willd.) & Shatawari & Asparagaceae \\
\hline 3 & $\begin{array}{l}\text { Chlorophytum borivilianum } \\
\text { (Santapau \& R.R. Fern) }\end{array}$ & Safedmusli & Asparagaceae \\
\hline 4 & Convolvulus arvensis $\mathrm{L}$. & Hirankhuri & Convolvulaceae \\
\hline 5 & Curculigo orchioides ( Gaertn) & Kalimusli & Hypoxidaceae \\
\hline 6 & Curcuma angustifolia ( Roxb.) & Tikur & Zingiberaceae \\
\hline 7 & Cynodon dactylon ( L.) Pars. & Dhoob grass & Poaceae \\
\hline 8 & Echinochloa colonum (L.) Link. & Motha & Poaceae \\
\hline 9 & Gloriosa superba (L.) & Jhagdahin & Colchicaceae \\
\hline 10 & Hemidesmus indicus (L.) R.Br. & Anantmul & Asclepiadacae \\
\hline 11 & Imperata cylindrica (Beauv) & Sirbaher & Poaceae \\
\hline 12 & Ocimum tenuiflorum $(\mathrm{L})$. & Tulsi & Lamiaceae \\
\hline 13 & Parthenium hysterophorus (L.) & Gajargass & Asteraceae \\
\hline 14 & Senna tora (L.) Roxb. & Charota & Fabaceae \\
\hline 15 & Tagetes minuta $\mathrm{L}$. & Mongra & Asteraceae \\
\hline 16 & Urginea indica (Roxb.) Kunth & Godli & Liliaceae \\
\hline
\end{tabular}


Table.3 IVI values of tree layer in different vegetation types in Khuriya Forest Range of Mungeli Forest Division Chhattisgarh, India

\begin{tabular}{|c|c|c|c|c|c|c|c|}
\hline $\begin{array}{l}\text { S. } \\
\text { No. }\end{array}$ & Botanical Name & Family & $\begin{array}{l}\text { Mixed } \\
\text { Forest }\end{array}$ & $\begin{array}{l}\text { Mixed } \\
\text { Sal }\end{array}$ & $\begin{array}{l}\text { Mixed } \\
\text { Teak }\end{array}$ & $\begin{array}{l}\text { Teak } \\
\text { Mixed }\end{array}$ & $\begin{array}{l}\text { Bamboo } \\
\text { Brake }\end{array}$ \\
\hline 1 & Adina cordifolia (Roxb.) Hook.F & Rubiaceae & 13.49 & 15.1 & 8.93 & 7.28 & - \\
\hline 2 & Anogeissus latifolia (Roxb ) & Combretaceae & 3.58 & 17.1 & - & - & - \\
\hline 3 & Bauhinia malabarica (Roxb.) & Leguminosae & 2.66 & 2.0 & - & - & - \\
\hline 4 & Bauhinia racemosa (Lam.) & Fabaceae & 0.50 & - & - & - & 18.11 \\
\hline 5 & Bombax ceiba (L.) & Bombaceae & 0.12 & - & - & - & - \\
\hline 6 & Bridelia retusa (L.) A. Juss. & Euphorbiaceae & 14.09 & 4.9 & 10.9 & - & - \\
\hline 7 & Buchanania lanzan (Spreng.) & Anacardiaceae & 0.29 & 8.7 & 4.66 & - & - \\
\hline 8 & Butea monosperma (Lam.) Taub & Fabaceae & 1.45 & - & - & - & 9.03 \\
\hline 9 & Careya arborea (Roxb.) & Myrtaceae & 2.25 & 1.6 & 2.27 & - & \\
\hline 10 & Cassia fistula (L.) & Fabaceae & - & - & 2.29 & 4.26 & 8.57 \\
\hline 11 & Chloroxylon swietenia (Roxb.) DC. & Rutaceae & 1.19 & - & - & - & \\
\hline 12 & Cleistanthus collinus ( Roxb.) & Phyllanthaceae & 3.93 & 23.4 & 9.62 & - & 8.68 \\
\hline 13 & Cordia dichotoma ( G Forst) & Boroginales & 1.44 & - & - & - & - \\
\hline 14 & Couroupita guianensis (Aubl.) & Lecythidaceae & 3.14 & - & 31.41 & 4.29 & - \\
\hline 15 & Dalbergia paniculata ( Roxb.) & Fabaceae & 0.12 & - & - & - & - \\
\hline 16 & Dendrocalamus strictus ( Roxb.) & Poaceae & 0.85 & - & - & - & 220.95 \\
\hline 17 & Dillenia pentagyna (Roxb.) & Dilleniaceae & 1.87 & - & - & - & - \\
\hline 18 & Diospyros ebenum (J. König) & Ebenaceae & 6.93 & - & 34.45 & - & - \\
\hline 19 & Diospyros melanoxylon (Roxb.) & Ebenaceae & 2.50 & 8.0 & 6.54 & 26.07 & 11.78 \\
\hline 20 & Diospyros montana (Roxb.) & Ebenaceae & 2.98 & - & - & 15.79 & - \\
\hline 21 & Dolichandrone falcata (Seem.) & Bignoniaceae & 4.00 & 2.2 & - & - & - \\
\hline 22 & Grewia tiliifolia (Vahl.) & Tiliaceae & 3.33 & 1.8 & - & - & - \\
\hline 23 & Lagerstroemia speciosa (L.) Pers. & Lythraceae & 5.31 & 8.1 & 19.5 & 27.59 & - \\
\hline 24 & Lannea coromandelica (Hout.) Merr. & Anacardiaceae & 3.49 & - & - & - & - \\
\hline 25 & Madhuca longifolia (J. Konig) & Sapotaceae & 7.34 & 8.3 & 4.72 & - & - \\
\hline 26 & Mallotus philippinensis (Lam.) & Euphorbiaceae & 2.30 & 3.4 & 5.29 & - & - \\
\hline 27 & Morinda tinctoria (Roxb.) & Rubiaceae & 1.37 & 8.7 & - & - & - \\
\hline 28 & Ougeinia oojeinensis (Roxb. ) & Fabaceae & 0.93 & 1.7 & 2.81 & - & - \\
\hline 29 & Phyllanthus emblica (L.) & Phyllanthaceae & 2.24 & 8.3 & - & - & - \\
\hline 30 & Pterocarpus marsupium (Roxb.) & Fabaceae & - & 1.9 & - & - & - \\
\hline 31 & Radermachera xylocarpa (Roxb.) & Bignoniaceae & 1.47 & 1.7 & - & - & - \\
\hline 32 & Schleichera oleosa (Lour.) Oken & Sapindaceae & - & 13.1 & - & - & - \\
\hline 33 & Semecarpus anacardium (Linn.) & Anacardiaceae & 2.05 & - & 8.25 & - & - \\
\hline 34 & Shorea robusta (Roth.) & Dipterocarpaceae & - & 116 & 7.50 & - & - \\
\hline 35 & Spondias mangifera (Will.) & Anacardiaceae & 0.07 & - & - & - & - \\
\hline 36 & Stephegyne parvifoliya (Roxb.) & Rubiaceae & - & 1.6 & - & - & - \\
\hline 37 & Sterculia urens (Roxb.) & Sterculiaceae & 0.51 & - & - & - & - \\
\hline 38 & Syzygium cumini (L.) Skeels. & Myrtaceae & 0.11 & 6.9 & 16.81 & 9.51 & - \\
\hline 39 & Tectona grandis & Lamiaceae & 0.96 & - & 120.7 & 205.2 & - \\
\hline 40 & Terminalia chebula (Retz.) & Combretaceae & - & 1.6 & - & - & - \\
\hline 41 & Terminalia tomentosa (Roxb.) & Combretaceae & - & 33.9 & 3.17 & - & 12.91 \\
\hline 42 & Vachellia nilotica (L.) & Fabaceae & - & - & - & - & 9.97 \\
\hline 43 & Ziziphus xylopyrus (Retz.) & Rhannaceae & 1.11 & - & - & - & - \\
\hline
\end{tabular}


Table.4 IVI of shrub, herbaceous and sapling layers in different vegetation types in Khuriya Forest Range of Mungeli Forest Division Chhattisgarh, India

\begin{tabular}{|c|c|c|c|c|c|c|c|}
\hline & \multicolumn{7}{|c|}{ Shrub layer } \\
\hline $\begin{array}{l}\text { S. } \\
\text { No. }\end{array}$ & Botanical Name & Family & $\begin{array}{l}\text { Mixed } \\
\text { Forest }\end{array}$ & $\begin{array}{l}\text { Mixed } \\
\text { Sal }\end{array}$ & $\begin{array}{l}\text { Mixed } \\
\text { Teak }\end{array}$ & $\begin{array}{l}\text { Teak } \\
\text { Mixed }\end{array}$ & $\begin{array}{l}\text { Bamboo } \\
\text { Brake }\end{array}$ \\
\hline 1 & Agave americana (L.) & Asparagaceae & - & - & - & - & 214 \\
\hline 2 & Bauhinia vahlii (Wight \& Arn.) & Caesalpiniceae & - & 43.87 & - & - & - \\
\hline 3 & Butea superba (Roxb.) & Fabaceae & 34.25 & 18.77 & - & 9.59 & - \\
\hline 4 & Dioscorea daemona (Roxb.) & Dioscoreaceae & 25.61 & - & - & - & - \\
\hline 8 & Dioscorea hispida (Dennst.) & Dioscoreaceae & - & - & 29.12 & - & - \\
\hline 6 & Gymnema sylvestre (Retz.) & Asclepiadaceae & 76.96 & 73.61 & 65.85 & 47.93 & - \\
\hline 7 & Ichnocarpus frutescens (Br.) & Apocyanaceae & 25.61 & - & - & - & - \\
\hline 5 & Jatropha curcus (L.) & Euphorbiaceae & - & - & 31.74 & - & 44.7 \\
\hline 9 & Milletia extensa (Benth.) & Fabaceae & - & - & 15.67 & - & - \\
\hline 11 & Nyctanthes arbor-tristis (L.) & Oleaceae & - & - & - & 75.78 & 41.3 \\
\hline 12 & Smilax ovalifolia (Roxb.) & Liliaceae & 103.33 & 144.83 & 134.28 & 101.62 & - \\
\hline 10 & Spatholobus roxburghii & Fabaceae & - & - & - & 15.57 & - \\
\hline \multirow[t]{2}{*}{13} & Ventilago denticulata (Willd) & Rhamnaceae & 34.25 & 18.92 & 23.34 & 49.51 & - \\
\hline & \multicolumn{7}{|l|}{ Herbaceous layer } \\
\hline 1 & Achyranthes aspera (Linn.) & Amaranthaceae & - & - & 19.8 & 21.65 & 33.24 \\
\hline 2 & Asparagus racemosus ( Willd.) & Asparagaceae & 6.69 & 13.41 & - & 5.14 & - \\
\hline 3 & $\begin{array}{l}\text { Chlorophytum borivilianum } \\
\text { (Santapau \& R.R. Fern) }\end{array}$ & Asparagaceae & 10.34 & - & - & 16.4 & - \\
\hline 4 & Convolvulus arvensis $\mathrm{L}$. & Convolvulaceae & 129 & 92.86 & 91.2 & 70.72 & 111.34 \\
\hline 5 & Curculigo orchioides ( Gaertn) & Hypoxidaceae & 30.85 & 42.51 & 30.8 & 26.15 & - \\
\hline 6 & Curcuma angustifolia ( Roxb.) & Zingiberaceae & 24.16 & 30.69 & - & 5.14 & - \\
\hline 7 & Cynodon dactylon ( L.) Pars. & Poaceae & - & - & 13.5 & 14.57 & 53.78 \\
\hline 8 & Echinochloa colonum (L.) Link. & Poaceae & 45.18 & 54.14 & 50.2 & 35.41 & 29.59 \\
\hline 9 & Gloriosa superba (L.) & Colchicaceae & 10.28 & 9.22 & - & - & - \\
\hline 10 & Hemidesmus indicus (L.) R.Br. & Asclepiadacea & - & 17.19 & 6.4 & 8.29 & - \\
\hline 11 & Imperata cylindrica (Beauv) & Poaceae & 10.34 & 18.51 & 26.8 & 30.28 & 42.47 \\
\hline 12 & Ocimum tenuiflorum (L.) & Lamiaceae & - & - & - & 39.87 & - \\
\hline 13 & Parthenium hysterophorus (L.) & Asteraceae & - & - & 28.9 & 5.14 & - \\
\hline 14 & Senna tora (L.) Roxb. & Fabaceae & 18.66 & 6.13 & 32.3 & 13.43 & 29.59 \\
\hline 15 & Tagetes minuta $\mathrm{L}$. & Asteraceae & - & - & - & 7.8 & - \\
\hline 16 & Urginea indica (Roxb.) Kunth & Liliaceae & 14.50 & 15.34 & - & - & - \\
\hline
\end{tabular}


Table.5 Diversity indices of vegetation types for Trees layer in Khuriya Forest Range of Mungeli Forest Division Chhattisgarh, India

\begin{tabular}{|l|c|c|c|c|c|c|c|c|c|c|c|c|c|c|c|}
\hline $\begin{array}{l}\text { Forest } \\
\text { type }\end{array}$ & \multicolumn{3}{|c|}{ Simpson Index } & \multicolumn{3}{|c|}{ Shannon Index } & \multicolumn{3}{|c|}{ Evenness Index } & \multicolumn{2}{c|}{ Margalefs Index } & \multicolumn{3}{c|}{ Beta Diversity } \\
\hline & Tree & Shrub & Herb & Tree & Shrub & Herb & Tree & Shrub & Herb & Tree & Shrub & Herb & Tree & Shrub & Herb \\
\hline $\begin{array}{l}\text { Mixed } \\
\text { Forest }\end{array}$ & 0.06 & 0.367 & 0.01 & 3.07 & 1.19 & 0.62 & 0.86 & 0.67 & 0.27 & 16.9 & 1.127 & 2.58 & 3.60 & 3.75 & 3.03 \\
\hline $\begin{array}{l}\text { Mixed } \\
\text { Sal }\end{array}$ & 0.32 & 0.34 & 0.27 & 1.80 & 1.27 & 1.66 & 0.57 & 0.79 & 0.72 & 9.26 & 0.91 & 2.43 & 2.96 & 2.94 & 3.03 \\
\hline $\begin{array}{l}\text { Mixed } \\
\text { Teak }\end{array}$ & 0.45 & 0.27 & 0.25 & 1.32 & 1.54 & 1.69 & 0.46 & 0.86 & 0.77 & 7.44 & 1.05 & 2.25 & 3.15 & 3.52 & 2.57 \\
\hline $\begin{array}{l}\text { Teak } \\
\text { Mixed }\end{array}$ & 0.73 & 0.33 & 0.20 & 0.61 & 1.32 & 2.01 & 0.29 & 0.74 & 0.76 & 5.30 & 0.826 & 3.51 & 3.07 & 2.4 & 2.8 \\
\hline $\begin{array}{l}\text { Bamboo } \\
\text { brake }\end{array}$ & 0.74 & 0.70 & 0.23 & 0.63 & 0.54 & 1.59 & 0.30 & 0.49 & 0.89 & 7.95 & 0.60 & 1.75 & 3.33 & 2.14 & 1.5 \\
\hline
\end{tabular}

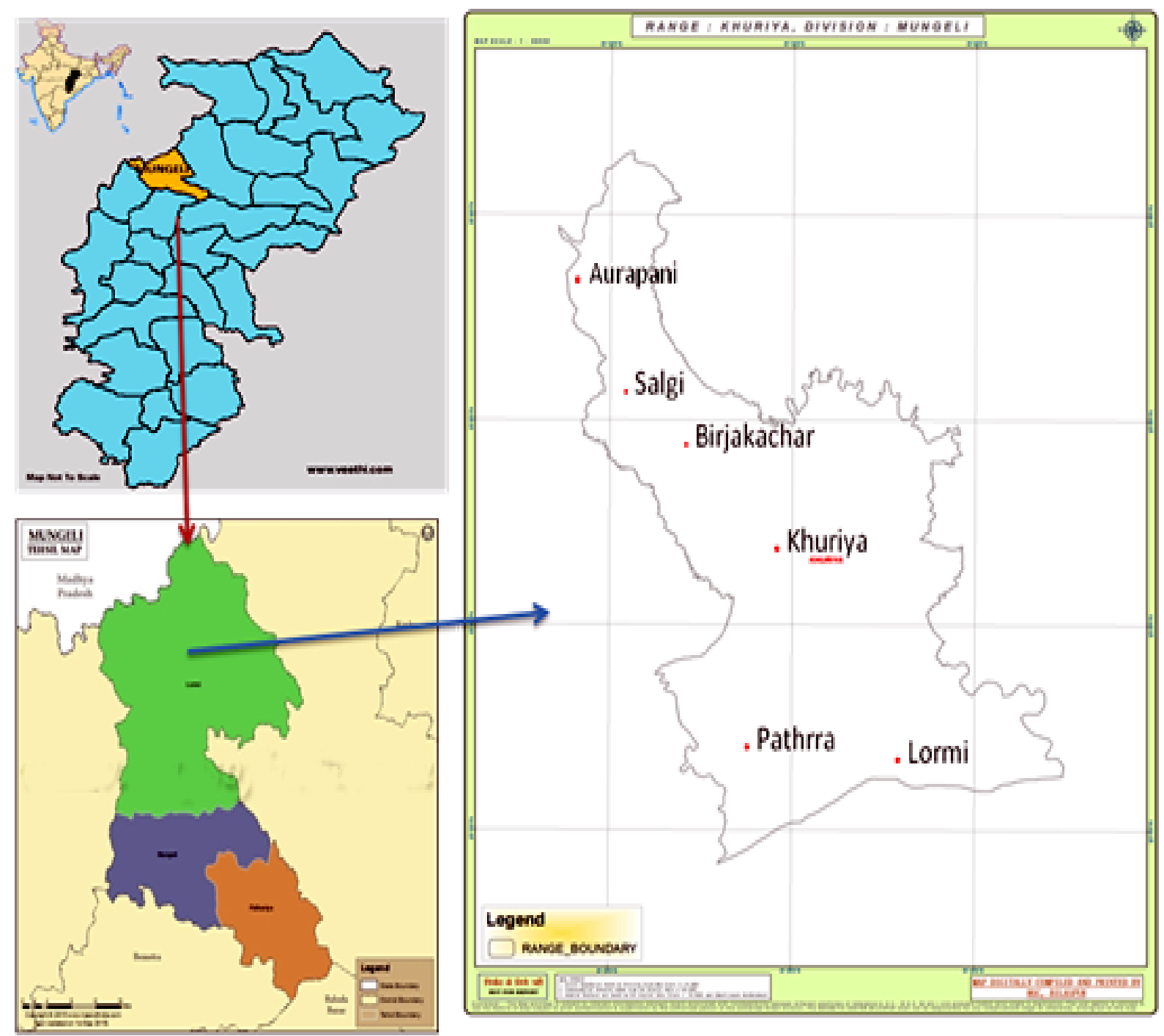

Fig.1 Study area of Khuriya Forest Range, Mungeli Forest Division Chhattisgarh, India 


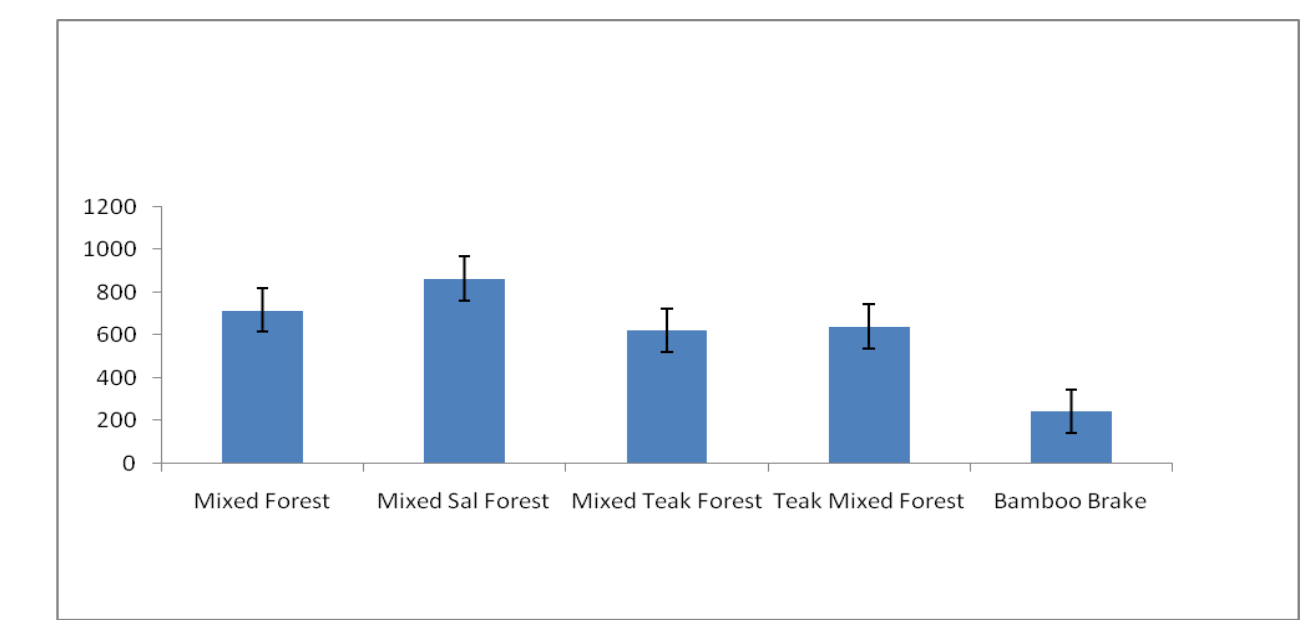

Fig.2 Density of tree layer in Khuriya Forest Range of Mungeli Forest Division Chhattisgarh, India

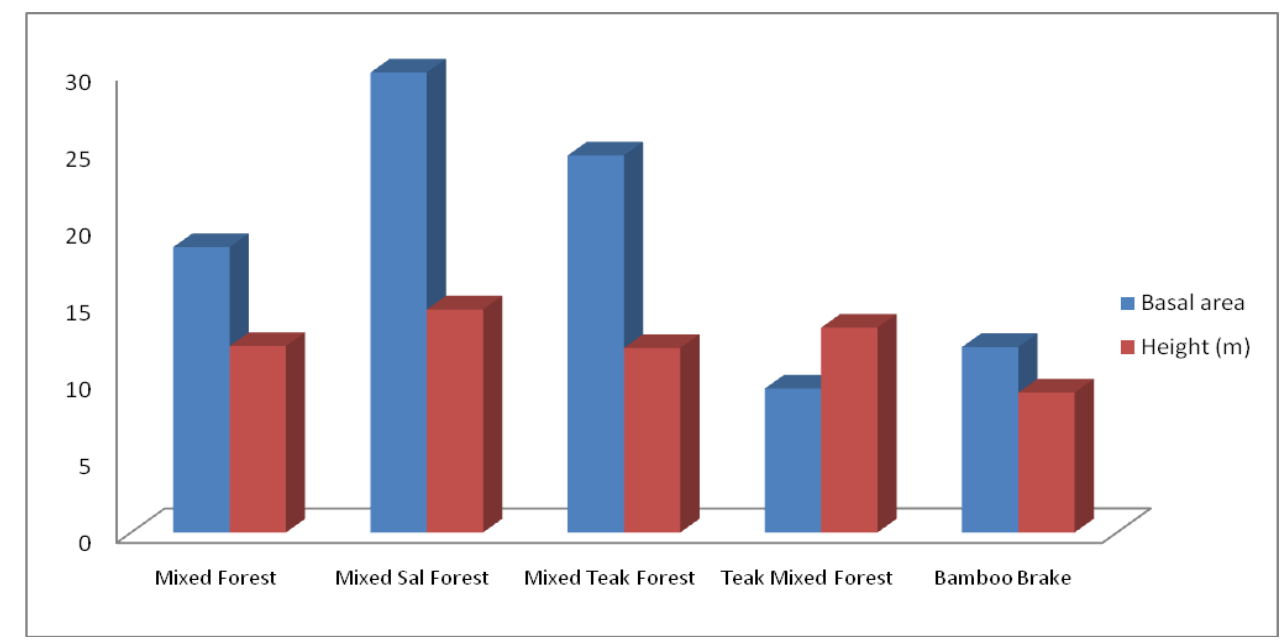

Fig.3 Basal area and crop height of tree layer in Khuriya Forest Range of Mungeli Forest Division Chhattisgarh, India

The biosphere inhabited by major tribes like Baiga, Gonds, Oraons, Pradhan, Kols, Samras etc. Biotic pressure is quite high in buffer zone and tribal masses extracts wide variety of wood and non-wood forest products round the year to meet their domestic needs and also market the surplus for augmenting household income. The illegal encroachment in dense forests is often seen in buffer zone and also prevalent in Khuriya range as most of such lands are brought under paddy cultivation.

The study revealed degradation of forests, the moist Sal forests are transforming into mixed Sal and dry Sal forests. The replacement of Sal by teak is also occurring in degraded patches due to anthropogenic pressure and climate change process. Therefore, there is need of conservation of natural composition in Mixed Sal and Mixed forests, whereby the structure and diversity could be maintained.

This could be possibly only through controlling disturbing factors leaving the vegetation to regenerate naturally. Forest patches would in that case serve as 'regeneration nuclei' for development of forest species (Belsky and Amundson 1992). The natural regeneration of $\mathrm{Sal}$ and Terminalias need to be saved from die back, which is common problem. Fire and grazing 
events need to be prevented so that young regeneration will not be affected. In spite of natural and anthropogenic disturbances, the remnant patches of Sal and Mixed forests in certain pockets holding many woody species, unique structures, and diversity could suffice natural regeneration if these were undisturbed.

But serious efforts for long term protection and conservation measures are necessary not only to rehabilitate the degraded forests of Mixed Sal forests but also maintain the native diversity of AABR. The study clearly demonstrated that vegetation of $\mathrm{AABR}$ is unique in terms of structure, composition and diversity in different forest types. The anthropogenic pressure was high in the Khuriya range, the selective logging and harvesting causing losses in structure and functioning of the vegetation in these forests. The encroachment in Mixed Forest and Mixed Sal Forests are also reduced the species richness and diversity levels.

Therefore, there is need of closure and protection of these vulnerable types for conservation of biodiversity in fragile zones. This will not only affect the well-being of large population of indigenous, whose livelihoods and economy are intricately linked with the forest wealth. It is essential to implement suitable policies and involve local people for community based approach for sustainable management of forests to secure the interests of both local and global communities.

\section{References}

Aiba, S.I., Takyu, M. and Kitayama, K. (2005) Dynamics, productivity and species richness of tropical rainforests along elevational and edaphic gradients on Mount Kinabalu, Borneo. Ecological
Research, 20, 279-286.

Bargali, S.S., Pandey, V.P. and Bargali, K. (2014) Floral composition and diversity pattern in open and closed dry deciduous forest. Vegetos 27(2):149-157.

Belsky, A.J., Amundson. (1992) Effects of grazing, competition, disturbance and fire on species composition and diversity in grassland communities. Journal of Vegetation Science, https:doi.org10.2307/3235679.

Bijalwan, A., Swamy, S. L., Sharma, C. M., Sharma, N. K. and Tiwari A.K. (2010) Land-use, biomass and carbon estimation in dry tropical forest of Chhattisgarh region in India using satellite remote sensing and GIS. Journal of Forestry Research 21(2): 161-170.

Curtis J.T. and McIntosh R.P. (1950) The interrelations of certain analytic and synthetic phytosociological characters. Ecology, 31: 434- 455.

Huston, M. (1980) Soil nutrients and tree species richness in Costa Rican forests. J. Biogeogr. 7, 147157.

Jha, C.S. and Singh, J.S. (1990) Composition and dynamics of dry tropical forest in relation to soil texture. J Veg Sci. $1: 609-614$.

Jucker et al., (2018) Topography shapes the structure, composition and function of tropical forest landscapes. Ecology Letters 21: 989-1000.

Kittur, B. H., Swamy, S.L., Bargali, S.S., Jhariya, M.K. (2014) Wildland fires and moist deciduous forests of Chhattisgarh, India: divergent component assessment. Journal of Forestry Research 25(4): 857-866.

Koh, L. P., Sodhi, N.S., Brook, B.W., (2004) Ecological Correlates of Extinction Pronenessin Tropical Butterflies Conservation Biology, Pages 1571- 
1578 Volume 18, No. 6.

Krishnamurthy, Y.L., Prakash, H.M., Nanda, A., Krishnappa, M., Dattaraj, H.S. and Suresh, H.S. (2010) Vegetation structure and floristic composition of a tropical dry deciduous forest in Bhadra Wildlife Sanctuary, Karnataka, India. Tropical Ecology 51(2): 235246.

Margaleaf, R. (1958) Temporal succession and spatial heterogeneity in phytoplankton. In Perspectives in marine biology, Buzzati-Traverso (ed.) Univ. Calif. Press. Berkeley. pp 323-347.

Naidu, T. and Kumar, O. (2016) Tree diversity, stand structure, and community composition of tropical forests in Eastern Ghats of Andhra Pradesh, India. $J$ Asia Pac. Biodiversity xxx 1-7.

Phillips, E. A. (1959) Methods of vegetation study. Henry Holt, New York, p 107.

Pielou, E.C. (1969) Species diversity and pattern diversity in the study of ecological succession. Journal Theoretical Biology, 10:370-383.

Pimm, S.L., Raven, P. (2000) Extinction by numbers. Nature, Vol 403:24 www.nature.com.

Shannon C. E., Weaver W. (1963) The mathematical theory of communication. University of Illinois Press, Urbana, p 117.

Simpson, E. H. (1949) Measurement of diversity. Nature 163: 688.
Singh, L. and Singh, J. S. (1991) Species structure, dry matter dynamics and carbon flux of a dry tropical forest in India. Annals of Botany 68: 263-273.

Sullivan, M. J. P., et al., (2017) Diversity and carbon storage across the tropical forest biome. Sci. Rep. 7, 39102.

Thakur T. K. (2018) Diversity, composition and structure of understorey vegetation in the tropical forest of Achanakmaar Biosphere Reserve, India. Environment Sustainability. 1(2): 279-293.

Thakur, T. K., Swamy, S. L., Bijalwan, A. and Nain, A. S. (2014) Structure, composition and diversity analysis of dry tropical forest using geospatial techniques. Journal of Forestry Research. 3(5): 1-4.

Thakur, T., Padwar, G. K., Patel, D. K. and Bijalwan, A. (2019) Monitoring land use, species composition and diversity of moist tropical environ in Achanakmaar Amarkantak Biosphere reserve, India using satellite data. Biodiversity Int $J$. (4):162-172.

Whittaker, R. H. (1975) Communities and Ecosystems. Macmillan, New York.

Yadav, D. K., Ghosh, L. and Jhariya, M. K. (2019) Floristic composition and diversity in the forest fragments of dry and moist tropical forest. Journal of Plant Development Sciences 11(4):201-212.

\section{How to cite this article:}

Harischandra Darro, S. L. Swamy, Tarun Kumar Thakur and Alka Mishra. 2020. Floristic Composition, Structure, Diversity and Conservation Strategies for Rehabilitation of Dry Tropical Forests in Buffer Zone of Achanakmaar Amarkantak Biosphere Reserve (AABR), India. Int.J.Curr.Microbiol.App.Sci. 9(04): 650-663. doi: https://doi.org/10.20546/ijcmas.2020.904.079 